\title{
Listening Boredom, Listening Boredom Coping Strategies, and Listening Performance: Exploring the Possible Relationships in Saudi EFL Context
}

\author{
Muhammad Waleed Shehzad ${ }^{1}$, Khaled Besher Albesher ${ }^{2}$, Summaira Sarfraz ${ }^{1}$, Shazma Razzaq ${ }^{3}$ \\ ${ }^{1}$ National University of Computer and Emerging Sciences, Pakistan \\ ${ }^{2}$ Qassim University, Saudi Arabia \\ ${ }^{3}$ Universiti Utara Malaysia, Malaysia
}

\begin{abstract}
Correspondence concerning this article should be addressed to Muhammad Waleed Shehzad, Department of Sciences and Humanities, National University of Computer and Emerging Sciences, Islamabad, Lahore Campus, Pakistan. E-mail: waleed.shehzad@nu.edu.pk
\end{abstract}

\begin{abstract}
Researchers paid ample attention to an important variable called boredom in numerous contexts; however, limited research exists regarding the association of boredom with listening comprehension performance in EFL settings. Thus, the current study aims to establish the association between listening boredom and listening comprehension performance by deploying listening boredom coping strategies as a mediating construct. A quantitative research approach, and a cross-sectional and correlational research design was used to conduct this study. A listening comprehension test and questionnaires were used to gather the data from 313 Saudi EFL learners. Results directed that there exists a negative yet significant association between listening boredom and listening comprehension performance. In addition, listening boredom showed a positive and significant association with all of the four listening boredom coping strategies. Furthermore, three out of four listening boredom coping strategies (i.e., behavioral, cognitive, and behavioral avoidance) showed a positive and significant association with listening performance; however, cognitive avoidance strategies showed a significant yet negative association with listening comprehension performance. Lastly, results regarding mediation indicated that listening boredom coping strategies mediated the relationship between listening boredom and listening comprehension performance. Based on the results, various recommendations were presented to EFL learners, instructors, and policymakers.
\end{abstract}

Keywords: listening boredom, listening boredom coping strategies, listening comprehension performance, Saudi EFL learners

\section{Introduction}

The sentiments of the students play a substantial part in boosting their motivation and learning (Graesser \& D’Mello, 2012; Hökkä et al., 2019; Pekrun et al., 2002; Trevors et al., 2017). Past studies related to the sentiments of the students have majorly focused on their apprehension while taking a test. Nonetheless, there are limited studies on experiences related to boredom (Mann \& Robinson, 2009; Mora, 2011; Shehzad et al., 2020). One of the reasons of dearth of studies regarding boredom in comparison to other sentiments including anger and anxiety could be due to the unnoticeable nature of boredom (Nett et al., 2010). Past studies confirmed that the relationship between boredom and learning performance of the students is significant but negative (Pekrun et al., 2002; Shehzad et al., 2020; Tze et al., 2016). In simple terms, past studies' findings affirmed that boredom related sentiments have an adverse effect on the process of learning. Moreover, they revealed various causes of boredom including difficult tasks (Graesser \& D'Mello, 2012), deficiency of interest in the subject, and decreased level of motivation (Graesser et al., 2014).

Previous studies confirm that learners employ several strategies to cope with the boredom during academic tasks (e.g., chatting with peers, thinking about something else that is unrelated, trying to pay more attention to the topic at hand etc.) (Eren \& Coskun, 2016). The findings of the past studies found a positive and substantial association between boredom and boredom coping strategies (Eren, 2016; Finkielsztein, 2019; Nett et al., 2011, 
Shehzad et al., 2020). Furthermore, in a few recently conducted studies, boredom coping strategies was used as a mediating variable between boredom and performance in the domain of reading and mathematics (Shehzad et al., 2020; Eren \& Coskun, 2016).

The review of the previous studies affirmed that numerous scholars piloted studies on the notion of boredom in various disciplines including psychology, education, educational psychology (Mora, 2011; Sharp et al., 2017; van Tilburg \& Igou, 2017); however, there is a scarcity of research in foreign language setting. Few recently conducted studies recommended that future studies should consider carrying out studies in EFL settings (Kruk \& Zawodniak, 2018; Shehzad et al., 2020). Tze, Daniels, and Klassen (2016) affirmed that more research ought to be conducted on the concept of boredom, as it is one of the most frequently experienced feelings by the learners in an academic environment.

More particularly, in EFL setting, there is a scarcity of studies concerning the connection between boredom and four main language skills in general and listening skill in particular. Shehzad et al. (2020) conducted a study involving the association between boredom, boredom coping strategies and reading comprehension performance. The current study merely focuses on English listening skill as it plays a crucial role in the development of other productive (i.e., speaking and writing) as well as receptive skills (i.e., reading) (Alhaison, 2017; Oxford, 1993). A recent study affirmed that the government of Saudi Arabia devotes a considerable chunk of budget on curriculum designing, recruitment of English native speakers as teachers, language laboratories, and English language instructors' coaching courses (Rahman \& Alsaisoni, 2013). In addition, Saudi Ministry of Education aims to incorporate all major skills related to English language in Saudi EFL learners including listening skill (Rahman \& Alsaisoni, 2013).

Unfortunately, the data gathered from the International English Language Testing System (IELTS) (2019) website shows poor performance of Saudi EFL learners in terms of English listening skills. The average bands acquired by them in IELTS academic category are second lowest in the world, i.e. 5.4; whereas, situation is more appalling in IELTS general category, where average bands are 5.1, i.e., lowest in the world. The past literature also confirms that Saudi EFL students struggle in English listening skills and their performance is below the par (Hamouda, 2013; Mohamed, 2018; Oteir \& Aziz, 2017). Therefore, with the aim of attaining insights pertinent to the alarming condition of Saudi students' English listening, it appears unavoidable to conduct an inter-field research concerning constructs that have not been investigated in relation to EFL listening comprehension performance. Consequently, this study intends to determine the relationship between listening boredom and listening comprehension performance of Saudi EFL learners by using listening boredom coping strategies (i.e., behavioral, cognitive, behavioral avoidance, cognitive avoidance) as a mediating variable. More precisely, this study intends to attain four objectives:

1. To determine the connection between listening boredom and listening comprehension performance.

2. To determine the connection between listening boredom and listening boredom coping strategies (i.e., behavioral, cognitive, behavioral avoidance, cognitive avoidance).

3. To determine the connection between listening boredom coping strategies (i.e., behavioral, cognitive, behavioral avoidance, cognitive avoidance) and listening comprehension performance.

4. To determine the mediating role of listening boredom coping strategies (i.e., behavioral, cognitive, behavioral avoidance, cognitive avoidance) between listening boredom and listening comprehension performance.

\section{Literature Review}

\section{Listening Comprehension Performance}

Numerous definitions regarding 'listening comprehension' can be found in the previous literature. According to Brown and Yule (1983), it denotes that a listener comprehends what his/her ears receive. In simple words, if a listener learns the intended message via hearing, he/she will comprehend it. Dirven and Oakeshott-Taylor (1984) described it as an outcome of teaching methodology and is considered analogous to several terms including speech comprehension, spoken language comprehension, and speech perception. Hamouda (2013) and Rost (2002) defined it as a collaborative process to create meaning involving listeners. Verbal utterance is 
comprehended by listeners via numerous linguistic and non-linguistic hints that include sound discrimination, stress and intonation, schematic knowledge, and grammatical constructions. According to Nadig (2013), it comprises numerous processes that are responsible for comprehension of verbal language including recognition of speech sounds, recognition of syntax of phrases and sentences, comprehension of meaning of distinct words.

Listening comprehension is considered as a crucial skill that L2 language users need to develop to learn the target language effectively (Vandergrift, 2007). Listening is deemed as the major route for language input and acquirement (Krashen, 1981; Osada, 2004) and an indispensable characteristic of communicative competency (Richards, 2008), which can assist the development of the remaining language skills (Vandergrift \& Goh, 2012).

The importance of listening comprehension is evident from the aforementioned literature. Owing to its importance, several scholars conducted research on this crucial variable. For instance, rigorous review of the literature revealed that many studies were carried out regarding the influence of listening instruction on listening comprehension performance (Fathi, \& Hamidizadeh, 2019; Namaziandost et al., 2020). In addition, several studies determined the influence of teaching methods on listening comprehension (Djabbarova, 2020; Etemadfar et al., 2020). Furthermore, few researchers determined the role of captions/ subtitles in listening comprehension (Hsieh, 2020; Hwang et al., 2019). Moreover, numerous researchers evaluated the impact of linguistic variables on listening comprehension including vocabulary knowledge (Li, 2019), and pronunciation awareness (Rahbar et al., 2020). Various researchers considered technology-related variables and determined its influence on listening comprehension performance including computer assisted language learning (CALL) (Abdolrezapour, 2019), and mobile assisted language learning (MALL) (Salih, 2019). A vast number of studies exist regarding the association of psychological variables with listening comprehension performance including motivation (Baleghizadeh \& Rahimi, 2011), anxiety (Zhang, 2013), emotional intelligence (Froiland \& Davison, 2019), self-efficacy (Ramli et al., 2019). However, a significant gap still exists in the literature regarding the relationship of a very crucial psychological variable, i.e., boredom and listening comprehension performance. Thus, the current study fills this gap by determining the relationship between listening boredom and listening comprehension performance by employing listening boredom coping strategies as a mediator.

\section{Boredom and Boredom Coping Strategies}

Numerous researchers incorporated the notion of boredom in several domains including language learning (Zawodniak et al., 2017), education (Sharp et al., 2019), psychology (Westgate \& Wilson, 2018), and therefore, they named it as an academic boredom (Acee et al., 2010), workplace boredom (Fisher, 1993), and relational boredom (Harasymchuk \& Fehr, 2010). Owing to the intense interest in the notion of boredom, the scholars offered numerous definitions. Most of them reflect boredom as a destructive feeling that has a negative impact on the individual's accomplishment. For instance, according to Conrad (1997), when a person does not take significant interest in the current situation, he/she suffers from an unwanted condition known as boredom. In addition, according to Eastwood et al. (2012), boredom is considered as a psychological aversive situation, in which a person fails to engage in a task.

Pekrun (2006) offered a theory called control-value theory. According to this theory, there are two major kinds of sentiments, i.e., positive activating sentiments and negative deactivating sentiments. Positive activating sentiments include hopefulness, joy, dignity etc. Whereas, negative deactivating sentiments include despair, boredom etc. (Pekrun, 2006). Pekrun (2006) affirmed that negative deactivating sentiments including boredom, unlike positive activating sentiments, have a negative yet substantial impact on learner's accomplishment. In order to confirm the aforementioned hypotheses of control-value theory, a recent study was conducted which analysed 29 studies and resolved that academic accomplishment was negatively and significantly affected by boredom (Tze et al., 2016). Intriguingly, previous literature confirmed that boredom showed more adverse influence on learners' academic accomplishment as compared to few of the other sentiments including apprehension, rage etc. (Pekrun et al., 2002). Conversely, few studies established a positive impact of boredom on learners' accomplishment (Harris, 2002).

The review of the past studies indicated that there exists a significant yet negative connection between boredom and several types of accomplishments including mathematical accomplishments, academic accomplishments, general studies accomplishments (Castens \& Overbey, 2009; Cowan \& Piepgrass, 1997; Eren \& Coskun, 2016; Pekrun et al., 2014; Putwain et al., 2018). Nevertheless, there exists a limited literature in EFL context (Kruk \& Zawodniak, 2018; Pawlak et al., 2020). More particularly, regarding the skills of English 
language, there exists only one study that determined the connection between boredom and reading comprehension performance (Shehzad et al., 2020).

As indicated previously, apart from getting bored, learners deploy several strategies to cope with the boredom feeling (Eren, 2013). Intriguingly, there is a dearth of studies that conducted research related to boredom coping strategies (Eren \& Coskun, 2016; Shehzad et al., 2020). This lack of studies could be attributed to the absence of an appropriate framework related to learners' boredom coping strategies. Thus, Nett et al. (2010) filled this gap by developing a thorough theoretical framework regarding boredom coping strategies. The strategies were segmented into subsequent four parts: behavioural strategies, behavioural-avoidance strategies, cognitive strategies, and cognitive-avoidance strategies. In cognitive strategies, people modify their viewpoints related to the boring situation, for example, by making themselves focused again on the topic under discussion. Behavioural strategies on the other hand require people to change a boring circumstance themselves by, for instance, introducing a topic that they believe the other students would be more interested in.

Contrariwise, the activities present in the cognitive-avoidance strategies are unconnected to the current scenario (e.g. preparing oneself for the next class during a lesson); whereas, the activities present in behavioural-avoidance strategies are related to the behavior of the learners that have no connection with the current situation (e.g., getting involved in a conversation with class fellows during a lesson) (Nett et al., 2010). Considering the above-mentioned framework related to boredom coping strategies, Nett et al. (2010) established a tool named coping with boredom scale. Several studies employed that scale in different contexts (Eren, 2013; Eren \& Coskun, 2016; Nett et al., 2011; Shehzad et al., 2020; Tze et al., 2016). Aforementioned research affirms that this particular tool could be employed in different contexts. Thus, the present research also deployed this model pertinent to boredom coping strategies. In addition, past studies found a substantial connection between numerous kinds of accomplishment and boredom coping strategies (Eren \& Coskun, 2016; Nett et al., 2010; Shehzad et al., 2020). Last but not the least, boredom coping strategies have been deployed as a mediator in several past studies (Eren \& Coskun, 2016; Shehzad et al., 2020; Zhou \& Kam, 2017).

Based upon the review of the past studies, subsequent hypotheses were generated:

$\mathrm{H}_{1}$ : There exists a substantial and negative association between listening boredom and listening comprehension performance.

$\mathrm{H}_{2}$ : There exists a substantial and positive association between listening boredom and listening behavioral boredom coping strategies.

$\mathrm{H}_{3}$ : There exists a substantial and positive association between listening boredom and listening cognitive boredom coping strategies.

$\mathrm{H}_{4}$ : There exists a substantial and positive association between listening boredom and listening behavioral avoidance boredom coping strategies.

$\mathrm{H}_{5}$ : There exists a substantial and positive association between listening boredom and listening cognitive avoidance boredom coping strategies.

$\mathrm{H}_{6}$ : There exists a substantial and positive association between listening behavioral boredom coping strategies and listening comprehension performance.

$\mathrm{H}_{7}$ : There exists a substantial and positive association between listening cognitive boredom coping strategies and listening comprehension performance.

$\mathrm{H}_{8}$ : There exists a substantial and positive association between listening behavioral avoidance boredom coping strategies and listening comprehension performance.

$\mathrm{H}_{9}$ : There exists a substantial and positive association between listening cognitive avoidance boredom coping strategies and listening comprehension performance.

$\mathrm{H}_{10}$ : Listening behavioral boredom coping strategies act as a mediator in determining the association between listening boredom and listening comprehension performance.

$\mathrm{H}_{11}$ : Listening cognitive boredom coping strategies act as a mediator in determining the association between listening boredom and listening comprehension performance. 
$\mathrm{H}_{12}$ : Listening behavioral avoidance boredom coping strategies act as a mediator in determining the association between listening boredom and listening comprehension performance.

$\mathrm{H}_{13}$ : Listening cognitive avoidance boredom coping strategies act as a mediator in determining the association between listening boredom and listening comprehension performance.

\section{Conceptual Framework of the Study}

The conceptual framework of the current study is depicted in Figure 1. As can be seen in Figure 1, Listening Boredom acts as an independent variable. Listening Boredom Coping Strategies (i.e., behavioral, cognitive, behavioral avoidance, cognitive avoidance) is the mediating variable. Lastly, Listening Comprehension Performance is the dependent variable of the study.

\section{Figure 1}

Conceptual Framework

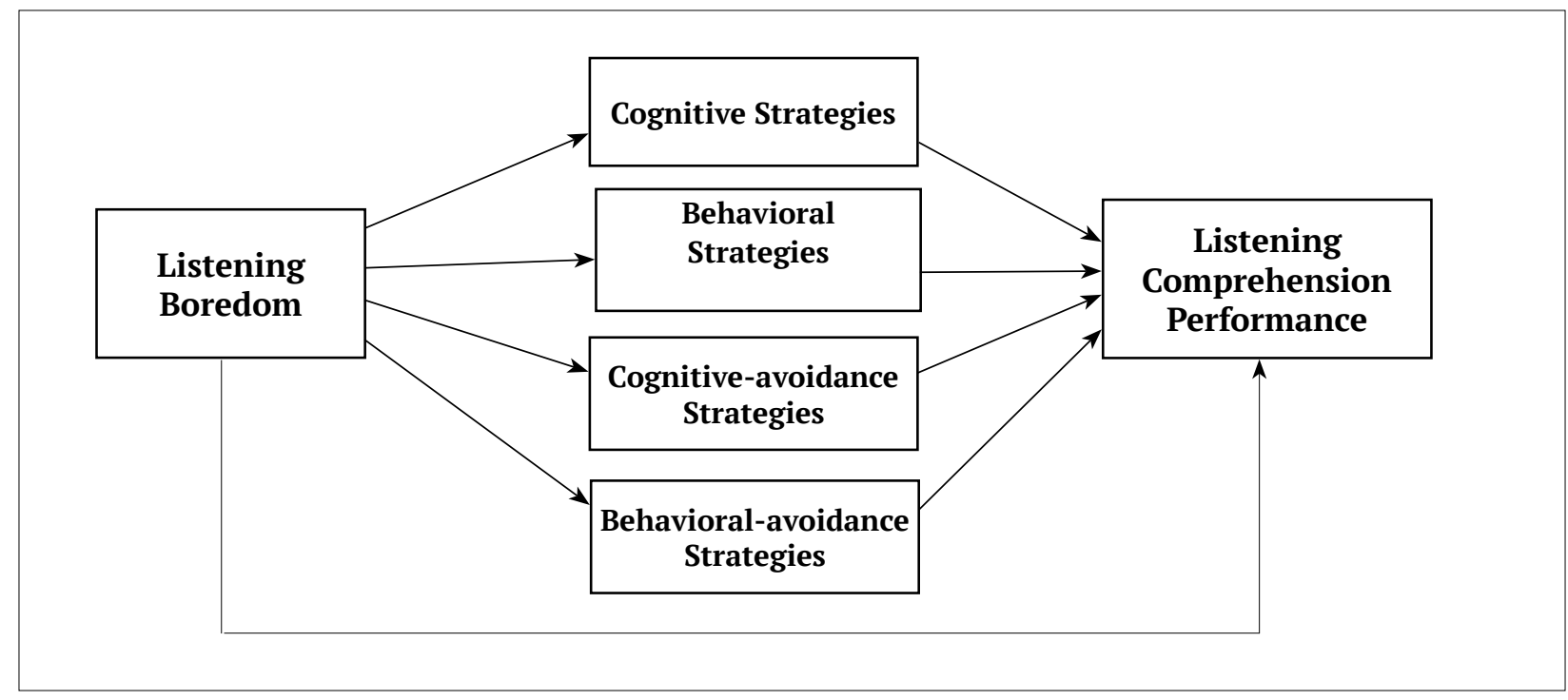

\section{Methodology}

\section{Research Design}

The current research deployed a quantitative research approach. In addition, a correlational and cross-sectional design was employed. In correlational research design, the association between variables is determined employing statistical procedures (Creswell, 2005). Thus, the current study specified the relationship between listening boredom and listening comprehension performance by deploying listening boredom coping strategies as a mediator.

\section{Sample}

A total of 313 Saudi EFL learners, both male and female participated in the study. More particularly, data was collected from second semester students of Preparatory Year Program (PYP) of five public sector universities in the central region of Kingdom of Saudi Arabia (KSA). Proportionate stratified random sampling was deployed to select the requisite number of students. As stated earlier, students were selected from five universities; thus, considering the total population of each of the universities, a certain fraction of the students was chosen. For instance, the strength of students in university D was highest as compared to the other universities; therefore, a larger sample was selected from it (refer to Table 1). In order to determine the appropriate sample size, a sampling table was used (Krejcie \& Morgan, 1970). According to this table, the appropriate sample size for the 
population of 1744 should be 313 . It is worth mentioning that prior to data collection process, the students were asked whether they agree to partake in this research. Therefore, the process of collecting the data formally set off after seeking permission of the subjects.

\section{Table 1}

\section{Statistics of sample}

\begin{tabular}{llccc}
\hline No. & Name of University & Population & Percentage & Questionnaires Disseminated \\
\hline 1 & University A & 455 & $26.08 \%$ & 81 \\
2 & University B & 389 & 22.30 & 70 \\
3 & University C & 327 & $18.75 \%$ & 59 \\
4 & University D & 419 & $24.02 \%$ & 75 \\
5 & University E & 154 & $8.83 \%$ & 28 \\
& Total & $\mathbf{1 7 4 4}$ & $\mathbf{1 0 0 \%}$ & $\mathbf{3 1 3}$ \\
\hline
\end{tabular}

\section{Instruments}

A total of three tools were deployed to gather the data containing a listening comprehension test and two questionnaires. To be more particular, in order to gather data regarding the independent construct, i.e., listening boredom, 'Level of Boredom Scale' containing seven statements having a five-point Likert scale was adapted from Shehzad et al. (2020). As the aforementioned instrument lies in the English reading domain; thus, it was modified to make it fit into English listening domain. In addition, 'Coping with Boredom Scale' was also adapted from Shehzad et al. (2020) to collect data regarding the mediator, i.e., listening boredom coping strategies. It consists of 20 statements having a five-point Likert scale. Last of all, a listening comprehension test based on Test of English as a Foreign Language (TOEFL) was adopted from Namaziandost et al. (2018) to evaluate the listening comprehension performance of Saudi EFL students. The test consists of 30 multiplechoice questions (MCQs). As evident from the previous study, the test has high reliability (i.e., 0.798) based on KR-21 method (Namaziandost et al., 2018).

\section{Data Collection Procedures}

The data were collected within five weeks (i.e., $19^{\text {th }}$ January 2020 to $23^{\text {rd }}$ of February 2020). Prior to data collection, a formal permission was sought from the deans of PYPs (Preparatory Year Programs) of five universities. Subsequently, we visited each of the five research sites to obtain catalogues of the students registered in PYP. After scrutinizing the catalogues, sample size was finalized. Afterwards, we administered the listening comprehension test and questionnaires. It is important to mention here that the subjects were apprised of the objective of the study. They were also assured of the fact that their identities would be kept private. Subsequent to data collection, questionnaires were reassessed to detect any missing responses. Finally, the gathered data were processed for data analysis.

\section{Data Analysis}

In the first place, outliers and missing values were evaluated. It is evident from Table 2 that collected data do not have any outliers and missing values. Next, the normality of the collected data was evaluated by deploying the benchmark of Skewness and Kurtosis. According to the benchmark, Skewness' value is supposed to be lower than 2 and the Kurtosis' value is supposed to be lower than 7 (Curran et al., 1996). It is clear from Table 3 that main analysis can be done, as data is normal. Main analysis has two models (i.e., measurement model and structural model).

\section{Measurement Model}

The major purpose of evaluating a measurement model is to determine the reliability and validity of the constructs. To evaluate the measurement model, a statistical software called Smart PLS 3.0 was used. Therefore, factor loadings, convergent validity, average variance extracted (AVE), composite reliability, and discriminant validity were assessed. It was confirmed by Hair et al. (2010) that AVE and factor loadings' values must not be 
less than the prescribed benchmark of 0.5 (see Figure 2, Table 3, and Table 4). In addition, Fornell and Larcker (1981) affirmed that the value of CR must be greater than 0.7 (see Table 4).

Table 3 and 4 depict that all the values of CR, AVE, and factor loadings lie in a recommended range. In addition, external consistency of the model was assessed through discriminant validity as shown in Table 5 by deploying 'Heterotrait-Monotrait' (HTMT). Henseler et al. (2015) declared that the values of HTMT should not be higher than 0.85 . Table 5 provides evidence that the external validity of the model is determined.

\section{Table 2}

Data statistics

\begin{tabular}{|c|c|c|c|c|c|c|c|c|c|}
\hline & No. & Missing & Mean & Median & Min & Max & $\begin{array}{l}\text { Standard } \\
\text { Deviation }\end{array}$ & $\begin{array}{c}\text { Excess } \\
\text { Kurtosis }\end{array}$ & Skewness \\
\hline LCP1 & 1 & 0 & 3.22 & 3 & 1 & 7 & 2.098 & -1.08 & 0.433 \\
\hline BAV1 & 2 & 0 & 3.202 & 3 & 1 & 7 & 1.923 & -1.028 & 0.363 \\
\hline BAV2 & 3 & 0 & 2.821 & 2 & 1 & 7 & 2.109 & -0.381 & 0.977 \\
\hline BAV3 & 4 & 0 & 2.711 & 2 & 1 & 7 & 2.174 & -0.438 & 1 \\
\hline BAV4 & 5 & 0 & 2.884 & 2 & 1 & 7 & 2.126 & -0.497 & 0.925 \\
\hline BAV5 & 6 & 0 & 2.809 & 2 & 1 & 7 & 2.015 & -0.264 & 0.965 \\
\hline CAV1 & 7 & 0 & 2.769 & 2 & 1 & 7 & 2.279 & -0.581 & 1.006 \\
\hline CAV2 & 8 & 0 & 2.642 & 2 & 1 & 7 & 2.037 & 0.063 & 1.166 \\
\hline CAV3 & 9 & 0 & 2.803 & 2 & 1 & 7 & 1.852 & -0.052 & 0.936 \\
\hline CAV4 & 10 & 0 & 2.751 & 2 & 1 & 7 & 1.9 & 0.094 & 1.04 \\
\hline CAV5 & 11 & 0 & 2.728 & 2 & 1 & 7 & 2.066 & -0.243 & 1.024 \\
\hline BA1 & 12 & 0 & 2.809 & 2 & 1 & 7 & 1.981 & -0.194 & 0.974 \\
\hline BA2 & 13 & 0 & 2.792 & 2 & 1 & 7 & 2.191 & -0.52 & 0.964 \\
\hline BA3 & 14 & 0 & 2.694 & 1 & 1 & 7 & 2.282 & -0.519 & 1.034 \\
\hline BA4 & 15 & 0 & 2.659 & 2 & 1 & 7 & 2.038 & 0.041 & 1.16 \\
\hline BA5 & 16 & 0 & 2.78 & 2 & 1 & 7 & 2.117 & -0.179 & 1.136 \\
\hline CA1 & 17 & 0 & 3.341 & 3 & 1 & 6 & 1.575 & -1.11 & 0.184 \\
\hline CA2 & 18 & 0 & 3.243 & 3 & 1 & 6 & 1.73 & -1.426 & 0.147 \\
\hline CA3 & 19 & 0 & 3.324 & 3 & 1 & 6 & 1.576 & -1.295 & 0.105 \\
\hline CA4 & 20 & 0 & 3.237 & 3 & 1 & 6 & 1.619 & -1.394 & 0.163 \\
\hline CA5 & 21 & 0 & 3.191 & 3 & 1 & 6 & 1.625 & -1.514 & 0.022 \\
\hline LB1 & 22 & 0 & 3.283 & 3 & 1 & 6 & 1.6 & -1.34 & -0.002 \\
\hline LB2 & 23 & 0 & 3.26 & 3 & 1 & 6 & 1.622 & -1.328 & 0.301 \\
\hline LB3 & 24 & 0 & 3.237 & 3 & 1 & 6 & 1.64 & -1.45 & 0.018 \\
\hline LB4 & 25 & 0 & 3.266 & 3 & 1 & 6 & 1.62 & -1.375 & 0.171 \\
\hline LB5 & 26 & 0 & 3.26 & 3 & 1 & 6 & 1.654 & -1.431 & 0.05 \\
\hline LB6 & 27 & 0 & 3.162 & 3 & 1 & 6 & 1.706 & -1.491 & 0.097 \\
\hline LB7 & 28 & 0 & 3.301 & 3 & 1 & 6 & 1.645 & -1.45 & -0.02 \\
\hline
\end{tabular}


Figure 2

Measurement model

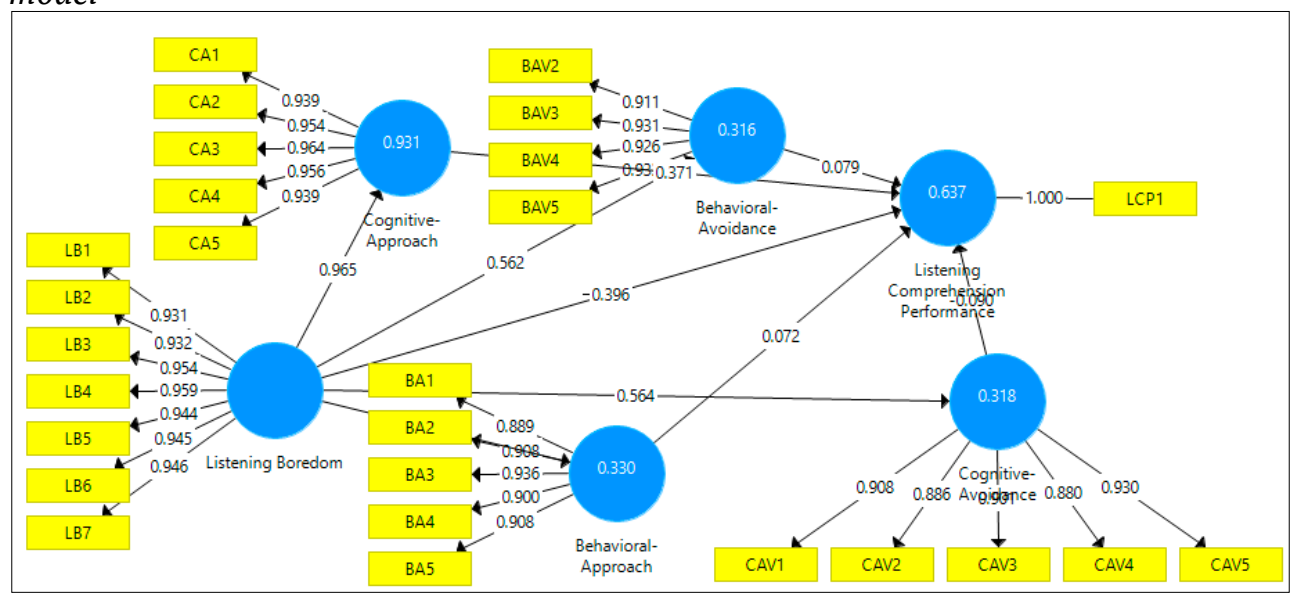

Table 3

Factor loadings

\begin{tabular}{|c|c|c|c|c|c|c|}
\hline & $\begin{array}{l}\text { Behavioral- } \\
\text { Approach }\end{array}$ & $\begin{array}{l}\text { Behavioral- } \\
\text { Avoidance }\end{array}$ & $\begin{array}{l}\text { Cognitive- } \\
\text { Approach }\end{array}$ & $\begin{array}{l}\text { Cognitive- } \\
\text { Avoidance }\end{array}$ & $\begin{array}{l}\text { Listening } \\
\text { Boredom }\end{array}$ & $\begin{array}{c}\text { Listening Comprehension } \\
\text { Performance }\end{array}$ \\
\hline BA1 & 0.889 & & & & & \\
\hline BA2 & 0.908 & & & & & \\
\hline BA3 & 0.936 & & & & & \\
\hline BA4 & 0.9 & & & & & \\
\hline BA5 & 0.908 & & & & & \\
\hline BAV2 & & 0.911 & & & & \\
\hline BAV3 & & 0.931 & & & & \\
\hline BAV4 & & 0.926 & & & & \\
\hline BAV5 & & 0.933 & & & & \\
\hline CA1 & & & 0.939 & & & \\
\hline CA2 & & & 0.954 & & & \\
\hline CA3 & & & 0.964 & & & \\
\hline CA4 & & & 0.956 & & & \\
\hline CA5 & & & 0.939 & & & \\
\hline CAV1 & & & & 0.908 & & \\
\hline CAV2 & & & & 0.886 & & \\
\hline CAV3 & & & & 0.901 & & \\
\hline CAV4 & & & & 0.88 & & \\
\hline CAV5 & & & & 0.93 & & \\
\hline LB1 & & & & & 0.931 & \\
\hline LB2 & & & & & 0.932 & \\
\hline LB3 & & & & & 0.954 & \\
\hline LB4 & & & & & 0.959 & \\
\hline LB5 & & & & & 0.944 & \\
\hline LB6 & & & & & 0.945 & \\
\hline LB7 & & & & & 0.946 & \\
\hline LCP1 & & & & & & 1 \\
\hline
\end{tabular}




\section{Table 4}

Reliability and convergent validity

\begin{tabular}{lcccc}
\hline & Alpha & rho_A & CR & AVE \\
\hline Behavioral-Approach & 0.947 & 0.95 & 0.959 & 0.825 \\
Behavioral-Avoidance & 0.944 & 0.947 & 0.96 & 0.856 \\
Cognitive-Approach & 0.973 & 0.973 & 0.979 & 0.903 \\
Cognitive-Avoidance & 0.942 & 0.945 & 0.956 & 0.812 \\
Listening Boredom & 0.98 & 0.98 & 0.983 & 0.893 \\
Listening Comprehension Performance & 1 & 1 & 1 & 1 \\
\hline
\end{tabular}

\section{Table 5}

HTMT

\begin{tabular}{lcccccc}
\hline & $\begin{array}{c}\text { Behavioral- } \\
\text { Approach }\end{array}$ & $\begin{array}{c}\text { Behavioral- } \\
\text { Avoidance }\end{array}$ & $\begin{array}{c}\text { Cognitive- } \\
\text { Approach }\end{array}$ & $\begin{array}{c}\text { Cognitive- } \\
\text { Avoidance }\end{array}$ & $\begin{array}{c}\text { Listening } \\
\text { Boredom }\end{array}$ & $\begin{array}{c}\text { Listening Comprehension } \\
\text { Performance }\end{array}$ \\
\hline Behavioral-Approach & 0.808 & & & & & \\
Behavioral-Avoidance & 0.732 & 0.825 & & & & \\
Cognitive-Approach & 0.576 & 0.561 & 0.85 & & \\
Cognitive-Avoidance & 0.861 & 0.623 & 0.562 & 0.801 & & 1 \\
Listening Boredom & 0.574 & 0.562 & 0.765 & 0.564 & 0.745 & 0.79 \\
Listening Comprehension & 0.501 & 0.494 & 0.789 & 0.484 & & \\
Performance & & & & & & \\
\hline
\end{tabular}

\section{Structural Model}

Bootstrapping feature was deployed to evaluate the structural model. Various researchers recommended that bootstrapping feature is considered as one of the most important steps in mediation analysis (Hayes, 2009; Zhao et al., 2010).Additionally, Hair et al. (2014) endorsed the usage of bootstrapping feature for studies involving mediating variables.

The outcomes of the bootstrapping are shown in Figure 3. More precisely, $t$-value, $p$-value, and path coefficients can be seen in Figure 3. Furthermore, the acceptance or rejection of research hypotheses regarding direct associations is depicted in Table 6.

\section{Figure 3}

\section{Structural model}

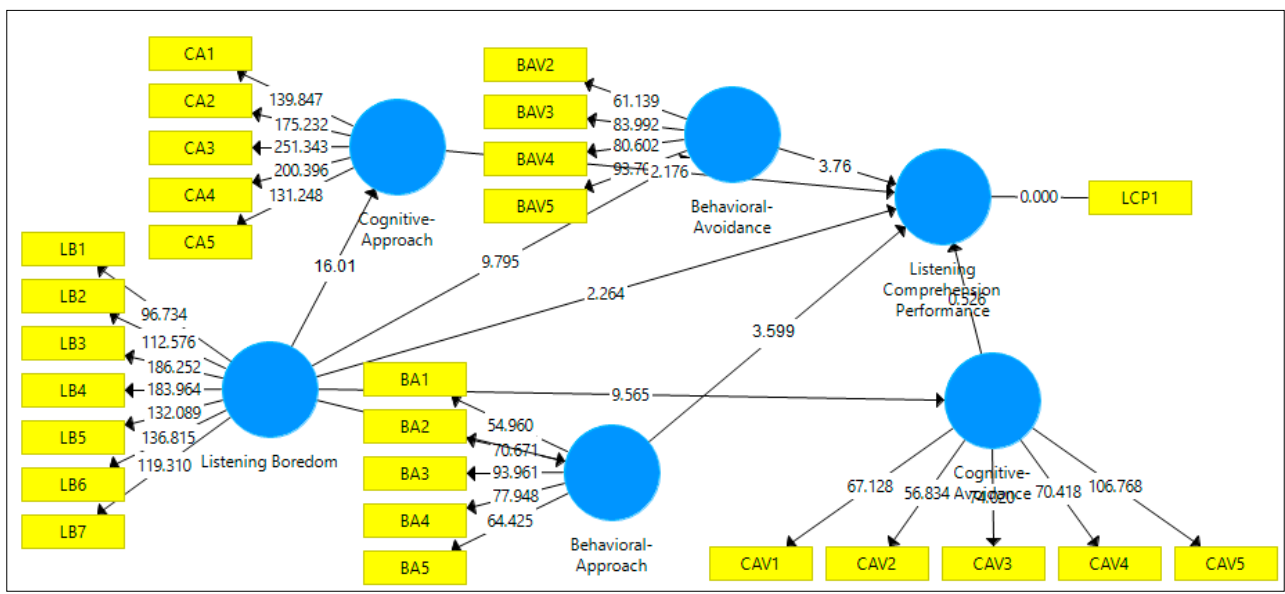


Table 6

Direct effect results

\begin{tabular}{|c|c|c|c|c|c|}
\hline & $\begin{array}{l}\text { Original } \\
\text { Sample }(0)\end{array}$ & $\begin{array}{c}\text { Sample } \\
\text { Mean (M) }\end{array}$ & $\begin{array}{l}\text { Standard Deviation } \\
\text { (STDEV) }\end{array}$ & $\begin{array}{l}\text { T Statistics } \\
(|O / S T D E V|)\end{array}$ & $\begin{array}{c}P \\
\text { Values }\end{array}$ \\
\hline $\begin{array}{l}\text { Behavioral-Approach -> Listening Comprehension } \\
\text { Performance }\end{array}$ & 0.072 & 0.075 & 0.02 & 3.599 & 0 \\
\hline $\begin{array}{l}\text { Behavioral-Avoidance -> Listening Comprehension } \\
\text { Performance }\end{array}$ & 0.079 & 0.073 & 0.021 & 3.76 & 0 \\
\hline $\begin{array}{l}\text { Cognitive-Approach -> Listening Comprehension } \\
\text { Performance }\end{array}$ & 0.371 & 0.363 & 0.171 & 2.176 & 0.03 \\
\hline $\begin{array}{l}\text { Cognitive-Avoidance -> Listening Comprehension } \\
\text { Performance }\end{array}$ & -0.09 & -0.088 & 0.172 & 0.526 & 0.599 \\
\hline Listening Boredom $->$ Behavioral-Approach & 0.574 & 0.58 & 0.059 & 9.714 & 0 \\
\hline Listening Boredom -> Behavioral-Avoidance & 0.562 & 0.568 & 0.057 & 9.795 & 0 \\
\hline Listening Boredom -> Cognitive-Approach & 0.965 & 0.965 & 0.06 & 16.01 & 0 \\
\hline Listening Boredom -> Cognitive-Avoidance & 0.564 & 0.57 & 0.059 & 9.565 & 0 \\
\hline $\begin{array}{l}\text { Listening Boredom -> Listening Comprehension } \\
\text { Performance }\end{array}$ & -0.396 & -0.406 & 0.175 & 2.264 & 0.024 \\
\hline
\end{tabular}

As seen in Table 6, hypotheses regarding direct associations (i.e., H1 to H9) are accepted. More particularly, findings regarding first research objective indicated that there exists a negative yet significant connection between listening boredom and listening comprehension performance $(\beta=-0.396$; $p$-value $=0.024)$. Furthermore, findings regarding second research objective indicated that listening boredom showed a positive and significant association with behavioral strategies $(\beta=0.574$; $p$-value $=0.000)$, cognitive strategies $(\beta=0.965$; $p$-value $=$ $0.000)$, behavioral avoidance strategies $(\beta=0.562$; p-value $=0.000)$, cognitive avoidance strategies $(\beta=0.965$; $\mathrm{p}$-value $=0.000$ ). Lastly, the findings of the third objective also showed a positive and significant association between listening comprehension performance and behavioral strategies $(\beta=0.072 ; p$-value $=0.000)$, cognitive strategies $(\beta=0.371 ; p$-value $=0.03)$, and behavioral avoidance strategies $(\beta=0.079 ; p$-value $=0.000)$. However, there exists a negative and significant association between listening comprehension performance and cognitive avoidance strategies $(\beta=-0.09 ; \mathrm{p}$-value $=0.599)$.

The outcomes of the mediation analysis are shown in Figure 3 and Table 7. $\beta$ value and p-value manifest that all the four listening boredom coping strategies act as a mediator in establishing the association between listening boredom and listening comprehension performance.

Table 7

Indirect effect results

\begin{tabular}{|c|c|c|c|c|c|}
\hline & $\begin{array}{c}\text { Original } \\
\text { Sample }(0)\end{array}$ & $\begin{array}{c}\text { Sample } \\
\text { Mean }(M)\end{array}$ & $\begin{array}{l}\text { Standard Deviation } \\
\text { (STDEV) }\end{array}$ & $\begin{array}{l}\text { T Statistics } \\
(|O / S T D E V|)\end{array}$ & $\begin{array}{c}P \\
\text { Values }\end{array}$ \\
\hline $\begin{array}{l}\text { Listening Boredom -> Behavioral-Approach -> Listening } \\
\text { Comprehension Performance }\end{array}$ & 0.041 & 0.046 & 0.011 & 3.713 & 0 \\
\hline $\begin{array}{l}\text { Listening Boredom -> Behavioral-Avoidance -> Listening } \\
\text { Comprehension Performance }\end{array}$ & 0.045 & 0.04 & 0.077 & 0.581 & 0.561 \\
\hline $\begin{array}{l}\text { Listening Boredom -> Cognitive-Approach -> Listening } \\
\text { Comprehension Performance }\end{array}$ & 0.358 & 0.35 & 0.164 & 2.179 & 0.03 \\
\hline $\begin{array}{l}\text { Listening Boredom -> Cognitive-Avoidance -> Listening } \\
\text { Comprehension Performance }\end{array}$ & -0.051 & -0.051 & 0.1 & 0.513 & 0.608 \\
\hline
\end{tabular}




\section{Results and Discussion}

This study aimed to attain four key objectives as stated earlier. Consequently, based upon past literature, four hypotheses were generated. The results of the first research objective showed that there exists a significant yet negative association between listening boredom and listening comprehension performance among Saudi EFL learners. Therefore, the aforementioned finding supports the first hypothesis. In simple words, results indicated that Saudi EFL learners' listening comprehension performance is reduced whenever they feel bored in English listening lessons. This particular result is in line with numerous past studies in the domain of mathematics (Castens \& Overbey, 2009; Cowan \& Piepgrass, 1997; Eren \& Coskun, 2016; Pekrun et al., 2014; Putwain et al., 2018). In EFL domain, this finding supports the finding of Shehzad et al. (2020), which confirmed that reading boredom is negatively associated with the reading comprehension performance. In addition to empirical studies, aforementioned finding also supports control-value theory, which affirms that the notion of boredom negatively affects the performance of the learners (Pekrun, 2006). The possible reason of the aforementioned finding could be attributed to the possibility that Saudi EFL learners might be kinesthetic learners. According to Al-Hebaishi (2012), kinesthetic learners learn best when they are allowed to get engaged in doing or touching anything while learning. He further elaborated that they get bored by just listening to lectures.

Additionally, the results of the second research objective designated that there exists a positive and substantial relationship between listening boredom and all of the four listening boredom coping strategies (i.e., behavioral, cognitive, behavioral avoidance, cognitive avoidance). This result supports several research hypotheses (i.e., $\mathrm{H} 2, \mathrm{H} 3, \mathrm{H} 4, \mathrm{H} 5$ ). Aforementioned result is in line with a number of previous studies (Eren \& Coskun, 2016; Nett et al., 2010; Shehzad et al., 2020), which indicate a positive and significant connection between boredom and all of the four boredom coping strategies. A thorough theoretical framework related to boredom coping strategies was established by Nett et al.(2010). They suggested that this framework ought to be incorporated in the future studies in different domains. Most of the past studies incorporated it in mathematics domain (Eren \& Coskun, 2016; Pekrun et al., 2014; Putwain et al., 2018), a recent study incorporated it in English reading domain (Shehzad et al., 2020); however, according to researcher's good knowledge, no study has incorporated it in English listening domain. Thus, the present research employed this framework and conducted a study in EFL listening domain as suggested by Nett et al. (2010).

In addition, the findings of the third research objective were in line with the numerous hypotheses (i.e., H6, H7, H8), which showed that there exists a positive and substantial association between listening boredom coping strategies and listening comprehension performance; however, one of the strategies (i.e., cognitive avoidance) showed a significant yet negative association with listening comprehension performance. Thus, H9 is rejected. In simple words, results designated that the usage of listening boredom coping strategies except one type (i.e., cognitive avoidance) resulted in the improvement of listening comprehension performance. Several studies confirm this finding (Eren \& Coskun, 2016; Nett et al., 2011; Shehzad et al., 2020). A recent study's findings asserted that the usage of these strategies not only assists students to reduce the feeling of boredom but also contributes in regulating their feelings and motivation level, which consequently improve their performance (Nett et al., 2020).

Finally, the results of the fourth research objective designated that all of the four listening boredom coping strategies (i.e., behavioral, cognitive, behavioral avoidance, cognitive avoidance) mediated the relationship between listening boredom and listening comprehension performance. Therefore, all the four hypotheses related to mediation (i.e., H10, H11, H12, H13) support this finding. This finding is in accordance with several studies (Shehzad et al., 2020; Zhou \& Kam, 2017). However, Eren and Coskun's (2016) outcomes are different from current study's findings. Their study on Turkish learners found that mathematics boredom coping strategies failed to mediate the connection between boredom and performance in mathematics domain.

\section{Conclusion}

The results attained from the current research can be valuable for EFL listening instructors, learners, syllabus designers, and policymakers. More particularly, EFL teachers can improve the listening comprehension performance of the learners by incorporating listening boredom coping strategies in their EFL listening lectures. Consequently, it is hoped that the students would take greater interest in the lessons, which would result in 
better listening comprehension. Syllabus designers should incorporate such content that is interesting and related to the culture of the EFL learners. Therefore, the listening comprehension performance of the learners would improve.

Despite the fact that the current research fills several substantial gaps; still, it has a few weaknesses. First, the current study has deployed a quantitative approach. It is believed that more robust results could have been obtained if qualitative approach had been deployed. Second, a cross-sectional design was deployed in this study owing to time restraints. However, the usage of longitudinal research design would have provided more reliability to the collected data as the data is collected multiple times in it. Third, current study did not consider private university students. Finally, yet importantly, the results of this study can only be generalized to the university students.

This study proposes numerous recommendations to other researchers. First, future researchers should consider conducting research using the same conceptual model on English writing and speaking skills since the reading and listening skills have already been explored by Shehzad et al. (2020) and the current study. Second, the future research studies regarding boredom ought to be conducted in EFL settings as also recommended by Kruk and Zawodniak (2018). Lastly, future studies should consider collecting data from EFL university students studying in both private and public sector universities.

\section{Declaration of Competing Interest}

None declared.

\section{References}

Abdolrezapour, P. (2019). Applying computer-mediated active learning intervention to improve L2 listening comprehension. Applied Research on English Language, 8(4), 511-530. https://doi.org/10.22108/ ARE.2019.115355.1424

Acee, T. W., Kim, H., Kim, H. J., Kim, J., Hsiang-Ning, R. C., Kim, M., \& Wicker, F. W. (2010). Academic boredom in under- and overchallenging situations. Contemporary Educational Psychology, 35(1), 17-27. https://doi. org/10.1016/j.cedpsych.2009.08.002

Alhaison, E. (2017). Metacognitive listening strategies used by Saudi EFL medical students. English Language Teaching, 10(2), 114-122.

Al-Hebaishi, S. M. (2012). Investigating the relationships between learning styles, strategies and the academic performance of Saudi English majors. International Interdisciplinary Journal of Education, 1(1028), 1-11. https://doi.org/10.12816/0002890

Al-Qahtani, A. (2016). Why do Saudi EFL readers exhibit poor reading abilities. English Language and Literature Studies, 6(1), 1-15. http://dx.doi.org/10.5539/ells.v6n1p1

Alshumaimeri, Y. (2017). The effects of reading method on the comprehension performance of Saudi EFL students. International Electronic Journal of Elementary Education, 4(1), 185-195.

Baleghizadeh, S., \& Rahimi, A. H. (2011). The relationship among listening performance, metacognitive strategy use and motivation from a self-determination theory perspective. Theory and Practice in Language Studies, 1(1), 61-67. https://doi.org/110.4304/tpls.1.1.61-67

Brown, G., \& Yule, G. (1983). Teaching the spoken language. Cambridge University Press.

Castens, A. R., \& Overbey, G. A. (2009). ADHD, boredom, sleep disturbance, self-esteem, and academic achievement in college students. Psi Chi Journal of Undergraduate Research, 14(2), 52-58.

Conrad, P. (1997). It's boring: Notes on the meanings of boredom in everyday life. Qualitative Sociology, 20, 465475. https://doi.org/10.1023/A:1024747820595

Cowan, M. M., \& Piepgrass, K. W. (1997). Attitudes about science among non-majors at the two-year campus of a liberal arts university (Report No. ED411034). Miami University.

Creswell, J. W. (2005). Educational research: Planning, conducting, and evaluating quantitative and qualitative approaches to research ( $2^{\text {nd }}$ ed.). Merrill/Pearson Education.

Curran, P. J., West, S. G., \& Finch, J. F. (1996). The robustness of test statistics to nonnormality and specification error in confirmatory factor analysis. Psychological Methods, 1(1), 16-29. https://psycnet.apa.org/ 
doi/10.1037/1082-989X.1.1.16

Danckert, J. (2019). Boredom: Managing the delicate balance between exploration and exploitation. In Boredom is in your mind (pp. 37-53). Springer. https://doi.org/10.1007/978-3-030-26395-9_3

Dirven, R., \& Oakeshott-Taylor, J. (1984). Listening comprehension (Part I). Language Teaching, 17(4), 326-343. https://doi.org/10.1017/S026144480001082X

Djabbarova, F. O. (2020). Modern methods of teaching listening skills. Science and Education, 1 (Special Issue 2).

Eastwood, J. D., Frischen, A., Fenske, M. J., \& Smilek, D. (2012). The unengaged mind: Defining boredom in terms of attention. Perspectives on Psychological Science, 7(5), 482-495. https://doi.org/10.1177/1745691612456044

Eren, A. (2013). Prospective teachers' perceptions of instrumentality, boredom coping strategies, and four aspects of engagement. Teaching Education, 24(3), 302-326. https://doi.org/10.1080/10476210.2012.724053

Eren,A.(2016). Unidirectional cycles of boredom, boredom coping strategies, and engagement among prospective teachers. Social Psychology of Education, 19(4), 895-924. https://doi.org/10.1007/s11218-016-9348-8

Eren, A., \& Coskun, H. (2016). Students' level of boredom, boredom coping strategies, epistemic curiosity, and graded performance. The Journal of Educational Research, 109(6), 574-588. https://doi.org/10.1080/0022067 1.2014.999364

Etemadfar, P., Soozandehfar, S. M. A., \& Namaziandost, E. (2020). An account of EFL learners' listening comprehension and critical thinking in the flipped classroom model. Cogent Education, 7(1), 1835150. https:// doi.org/10.1080/2331186X.2020.1835150

Fathi, J., \& Hamidizadeh, R. (2019). The contribution of listening strategy instruction to improving second language listening comprehension: A case of Iranian EFL learners. International Journal of Instruction, 12(2), 17-32. https://doi.org/10.29333/iji.2019.1222a

Finkielsztein, M. (2019). Class-related academic boredom among university students: a qualitative research on boredom coping strategies. Journal of Further and Higher Education, 43, 1-16. https://doi.org/10.1080/03098 77X.2019.1658729

Fisher, C. (1993). Boredom at work: A neglected concept. Human Relations, 46, 395-417.

Fornell, C., \& Larcker, D. F. (1981). Evaluating structural equation models with unobservable variables and measurement error.Journal of Marketing Research, 18(1), 39-50.https://doi.org/10.1177/002224378101800104

Froiland, J. M., \& Davison, M. L. (2019). Emotional intelligence, listening comprehension, and reading comprehension among diverse adolescents. Journal of Child and Family Studies, 29, 1385-1390 https://doi. org/10.1007/s10826-019-01557-8

Graesser, A. C., \& D’Mello, S. K. (2012). Emotions during the learning of difficult material. In B. H. Ross (Ed.), The psychology of learning and motivation (vol. 57, pp. 183-226). Academic Press.

Graesser, A. C., D’Mello, S. K., \& Strain, A. C. (2014). Emotions in advanced learning technologies. In R. Pekrun \& L. Linnenbrink-Garcia (Eds.), International handbook of emotions in education (pp. 473-493). Routledge.

Hair Jr, J. F., Sarstedt, M., Hopkins, L., \& Kuppelwieser, V. G. (2014). Partial least squares structural equation modeling (PLS-SEM). European Business Review, 26(2), 106-121. https://doi.org/10.1108/EBR-10-2013-0128

Hair Jr., J. F., Black, W. C., Babin, B. J., Andersen, R. E., \& Tatham, R. L. (2010). Mutilvariate data analysis (7th ed.). Pearson Prentice Hall.

Hamouda, A. (2013). An investigation of listening comprehension problems encountered by Saudi students in the EL listening classroom. International Journal of Academic Research in Progressive Education and Development, 2(2), 113-15.

Harasymchuk, C., \& Fehr, B. (2010). A script analysis of relational boredom: Causes, feelings, and coping strategies. Journal of Social and Clinical Psychology, 29(9), 988-1019. https://doi.org/10.1521/jscp.2010.29.9.988

Harris, M. B. (2000). Correlates and characteristics of boredom proneness and boredom. Journal of Applied Social Psychology, 30(3), 576-598. https://doi.org/10.1111/j.1559-1816.2000.tb02497.x

Hayes,A.F.(2009). Beyond Baron and Kenny: Statistical mediation analysis in the new millennium. Communication Monographs, 76(4), 408-420. https://doi.org/10.1080/03637750903310360

Henseler, J., Ringle, C. M., \& Sarstedt, M. (2015). A new criterion for assessing discriminant validity in variancebased structural equation modeling. Journal of the Academy of Marketing Science, 43(1), 115-135. https://doi. org/10.1007/s11747-014-0403-8

Hökkä, P., Vähäsantanen, K., \& Paloniemi, S. (2019). Emotions in learning at work: A literature review. Vocations and Learning, 13(1), 1-26. https://doi.org/10.1007/s12186-019-09226-z

Hsieh, Y. (2020). Effects of video captioning on EFL vocabulary learning and listening comprehension. Computer Assisted Language Learning, 33(5-6), 567-589. https://doi.org/10.1080/09588221.2019.1577898

Hwang, G. J., Hsu, T. C., \& Hsieh, Y. H. (2019). Impacts of different smartphone caption/subtitle mechanisms on English listening performance and perceptions of students with different learning styles. International 
Journal of Human-Computer Interaction, 35(4-5), 333-344. https://doi.org/10.1080/10447318.2018.1543091

IELTS Partners (British Council, IDP: IELTS Australia Pty Ltd., and Cambridge English Language Assessment). (2019). IELTS Researchers: Test Taker Performance 2019. Retrieved September 21, 2020, from IELTS website: https://www.ielts.org/teaching-and-research/test-taker-performance_2019.aspx

Krejcie, R. V., \& Morgan, D. W. (1970). Determining sample size for research activities. Educational and Psychological Measurement, 30(3), 607-610. https://doi.org/10.1177\%2F001316447003000308

Kruk, M., \& Zawodniak, J. (2018). Boredom in practical English language classes: Insights from interview data. In L. Szymański, J. Zawodniak, A. Łobodziec, M. Smoluk (Eds.), Interdisciplinary Views on the English Language, Literature and Culture (177-191). Zielona Góra.

$\mathrm{Li}, \mathrm{C}$. H. (2019). Using a listening vocabulary levels test to explore the effect of vocabulary knowledge on GEPT listening comprehension performance. Language Assessment Quarterly, 16(3), 328-344. https://doi.org/10.10 80/15434303.2019.1648474

Macklem, G. L. (2015). Boredom in the classroom: Addressing student motivation, self-regulation and engagement in learning. Springer.

Mann, S., \& Robinson, A. (2009). Boredom in the lecture theatre: An investigation into the contributors, moderators and outcomes of boredom amongst university students. British Educational Research Journal, 35(2), 243-258. https://doi.org/10.1080/01411920802042911

Meniado, J. C. (2016). Metacognitive reading strategies, motivation, and reading comprehension performance of Saudi EFL students. English Language Teaching, 9(3), 117-129. https://doi.org/10.5539/elt.v9n3p117

Mohamed, M. M. K. (2018). Using audiobooks for developing listening comprehension among Saudi EFL preparatory year students. Journal of Language Teaching and Research,9(1), 64-73. http://dx.doi.org/10.17507/ jltr.0901.08

Mora, R. (2011). "School is so boring": High stakes testing and boredom at an urban middle school. Penn GSE Perspectives on Urban Education, 9(1), 9-11.

Nadig, A. (2013). Listening comprehension. In F. R. Volkmar (Ed.), Encyclopedia of autism Spectrum disorders. Springer

Namaziandost, E., Rezaei, Z., Etemadfar, P., \& Alekasir, S. (2020). Implementing a flipped model of instruction in the EFL listening classroom: Impact on comprehension. Journal on English as a Foreign Language, 10(2), 385-401. https://doi.org/10.23971/jefl.v10i2.2065

Namaziandost, E., Sabzevari, A., \& Hashemifardnia, A. (2018). The effect of cultural materials on listening comprehension among Iranian upper-intermediate EFL learners: In reference to gender. Cogent Education, 5(1), 1560601. https://doi.org/10.1080/2331186X.2018.1560601

Nett, U. E., Goetz, T., \& Daniels, L. (2010). What to do when feeling bored? Students' strategies for coping with boredom. Learning and Individual Differences, 20(6), 626-638. https://doi.org/10.1016/j.lindif.2010.09.004

Nett, U. E., Goetz, T., \& Hall, N. C. (2011). Coping with boredom in school: An experience sampling perspective. Contemporary Educational Psychology, 36, 49-59. https://doi.org/10.1016/j.cedpsych.2010.10.003

Osada, N. (2004). Listening comprehension research: A brief review of the past thirty years. Dialogue, 3(1), 53-66.

Oteir, I., \& Aziz, N. H. A. (2017). Effects of listening comprehension anxiety from Saudi EFL learners' perspectives. International Journal of Linguistics, 9(5), 113-125. https://doi.org/10.5296/ijl.v9i5.11792

Oxford, R. L. (1993). Research update on teaching L2 listening. System, 21(2), 205-211. https://doi. org/10.1016/0346-251X(93)90042-F

Pawlak, M., Kruk, M., Zawodniak, J., \& Pasikowski, S. (2020). Investigating factors responsible for boredom in English classes: The case of advanced learners. System, 102259, 1-30. https://doi.org/10.1016/j. system.2020.102259

Pekrun, R. (2006). The control-value theory of achievement emotions: Assumptions, corollaries, and implications for educational research and practice. Educational Psychology Review, 18, 315-341. https://doi.org/10.1007/ s10648-006-9029-9

Pekrun, R., Goetz, T., Titz, W., \& Perry, R. P. (2002). Academic emotions in students' self-regulated learning and achievement: A program of qualitative and quantitative research. Educational Psychologist, 37(1), 91-105. https://doi.org/10.1207/S15326985EP3702_4

Pekrun, R., Hall, N. C., Goetz, T., \& Perry, R. P. (2014). Boredom and academic achievement: Testing a model of reciprocal causation. Journal of Educational Psychology, 106(3), 696-710. https://doi.org/10.1037/a0036006

Putwain, D. W., Becker, S., Symes, W., \& Pekrun, R. (2018). Reciprocal relations between students' academic enjoyment, boredom, and achievement over time. Learning and Instruction, 54, 73-81.https://doi.org/10.1016/j. learninstruc.2017.08.004

Rahbar, S., Ahangari, S., \& Saeidi, M. (2020). Raising the learners' awareness of prosodic features in pronunciation 
and its impact on listening comprehension: Insights from noticing hypothesis (Schmidt, 1995). Foreign Language Research Journal, 10(2), 260-271. https://doi.org/10.22059/jflr.2020.287970.674

Rahimirad, M. (2014). The impact of metacognitive strategy instruction on the listening performance of university students. Procedia-Social and Behavioral Sciences, 98, 1485-1491. https://doi.org/10.1016/j. sbspro.2014.03.569

Rahman, M. M., \& Alhaisoni, E. (2013). Teaching English in Saudi Arabia: Prospects and challenges. Academic Research International, 4(1), 112-118.

Ramli, M. N., Saukah, A., \& Prayogo, J. A. (2019). Word recognition from speech, syntactic knowledge, metacognitive awareness, self-efficacy as determination for 12 listening comprehension. International Journal of Instruction, 12(3), 89-104. http://doi.org/10.17576/3L-2020-2602-13

Richards, J. C. (2008). Teaching listening and speaking from theory to practice. Cambridge University Press.

Rost, M. (2002). Teaching and researching listening. Longman.

Salih, A. H. (2019). Effects of mobile assisted language learning on developing listening skill to the department of English students in college of education for women at Al Iraqia University. European Journal of Language and Literature, 5(1), 31-38. http://dx.doi.org/10.26417/ejls-2019.v5i1-191

Sharp, J. G., Hemmings, B., Kay, R., \& Sharp, J. C. (2019). Academic boredom and the perceived course experiences of final year Education Studies students at university. Journal of Further and Higher Education, 43(5), 601-627. https://doi.org/10.1080/0309877X.2017.1386287

Sharp, J. G., Hemmings, B., Kay, R., Murphy, B., \& Elliott, S. (2017). Academic boredom among students in higher education: A mixed-methods exploration of characteristics, contributors and consequences. Journal of Further and Higher Education, 41(5), 657-677. https://doi.org/10.1080/0309877X.2016.1159292

Shehzad, M.W., Ahmed, R., Razzaq, S., Akhtar, A., Hasan, M.K. (2020). Do reading boredom and boredom coping strategies predict reading comprehension performance? An investigation of Saudi EFL learners. Indonesian Journal of Applied Linguistics, 10(2), 445-459. https://doi.org/10.17509/ijal.v10i2.28616

Trevors, G. J., Muis, K. R., Pekrun, R., Sinatra, G. M., \& Muijselaar, M. M. (2017). Exploring the relations between epistemic beliefs, emotions, and learning from texts. Contemporary Educational Psychology, 48(1), 116-132. https://doi.org/10.1016/j.cedpsych.2016.10.001

Tze, V. M., Daniels, L. M., \& Klassen, R. M. (2016). Evaluating the relationship between boredom and academic outcomes: A meta-analysis. Educational Psychology Review, 28(1), 119-144. https://doi.org/10.1007/s10648015-9301-y

van Tilburg, W. A., \& Igou, E. R. (2017). Boredom begs to differ: Differentiation from other negative emotions. Emotion, 17(2), 309-322. https://doi.org/10.1037/emo0000233

Vandergrift, L. (2007). Recent developments in second and foreign language listening comprehension research. Language Teaching, 40(3), 191-221. https://doi.org/10.1017/S0261444807004338

Vandergrift, L., \& Goh, C. (2012). Teaching and learning second language listening: Metacognition in action. Routledge.

Vodanovich, S. J. (2003). Psychometric measures of boredom: A review of the literature. The Journal of Psychology, 137(6), 569-595. https://doi.org/10.1080/00223980309600636

Westgate, E. C., \& Wilson, T. D. (2018). Boring thoughts and bored minds: The MAC model of boredom and cognitive engagement. Psychological Review, 125(5), 689-713. https://doi.org/10.1037/rev0000097

Zawodniak, J., Kruk, M., \& Chumas, J. (2017). Towards conceptualizing boredom as an emotion in the EFL academic context. KSJ, 5(4), 425-441. https://doi.org/10.30438/ksj.2017.5.4.3

Zeng, Y. (2014). Investigating the effects of metacognitive instruction on Chinese EFL learners' listening performance. International Journal of Innovation in English Language Teaching and Research, 3(2), 139-157.

Zhang, X. (2013). Foreign language listening anxiety and listening performance: Conceptualizations and causal relationships. System, 41(1), 164-177. https://doi.org/10.1016/j.system.2013.01.004

Zhao, X., Lynch Jr, J. G., \& Chen, Q. (2010). Reconsidering Baron and Kenny: Myths and truths about mediation analysis. Journal of Consumer Research, 37(2), 197-206. https://psycnet.apa.org/doi/10.1086/651257

Zhou, M., \& Kam, C. C. S. (2017). Trait procrastination, self-efficacy and achievement goals: the mediation role of boredom coping strategies. Educational Psychology, 37(7), 854-872. https://doi.org/10.1080/01443410.201 7.1293801 